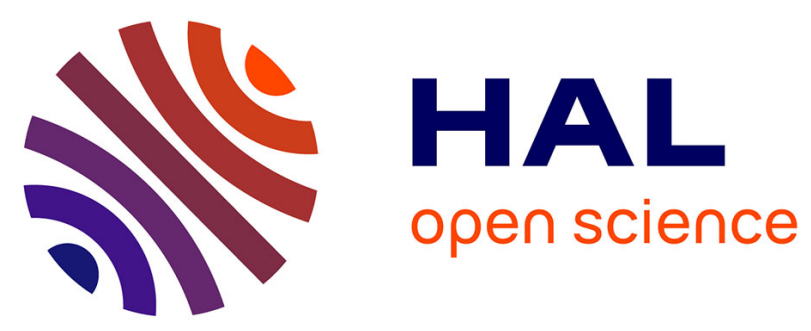

\title{
In vitro evaluation of the probiotic potential of Lactobacillus salivarius SMXD51
}

\author{
Soumaya Messaoudi, Amar Madi, Herve H. Prévost, Marc Feuilloley, \\ Mohamed Manai, Xavier X. Dousset, Nathalie Connil
}

\section{- To cite this version:}

Soumaya Messaoudi, Amar Madi, Herve H. Prévost, Marc Feuilloley, Mohamed Manai, et al.. In vitro evaluation of the probiotic potential of Lactobacillus salivarius SMXD51. Anaerobe, 2012, 18 (6), pp.584-589. 10.1016/j.anaerobe.2012.10.004 . hal-02651193

\section{HAL Id: hal-02651193 \\ https://hal.inrae.fr/hal-02651193}

Submitted on 29 May 2020

HAL is a multi-disciplinary open access archive for the deposit and dissemination of scientific research documents, whether they are published or not. The documents may come from teaching and research institutions in France or abroad, or from public or private research centers.
L'archive ouverte pluridisciplinaire HAL, est destinée au dépôt et à la diffusion de documents scientifiques de niveau recherche, publiés ou non, émanant des établissements d'enseignement et de recherche français ou étrangers, des laboratoires publics ou privés. 
Clinical microbiology

\title{
In vitro evaluation of the probiotic potential of Lactobacillus salivarius SMXD51
}

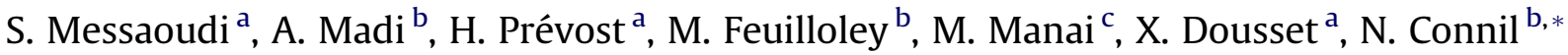 \\ ${ }^{a}$ LUNAM University, Oniris, UMR1014 Secalim, Nantes, France \\ ${ }^{\mathrm{b}}$ Laboratory of Microbiology Signals and Microenvironment EA4312, University of Rouen, 55 rue Saint Germain, Evreux, France \\ ${ }^{\mathrm{c}}$ Laboratory of Biochemistry and Molecular Biology, Faculty of Sciences of Tunis, Tunisia
}

\section{A R T I C L E I N F O}

\section{Article history:}

Received 25 July 2012

Received in revised form

13 October 2012

Accepted 23 October 2012

Available online 30 October 2012

\section{Keywords:}

Lactobacillus salivarius

Chicken probiotic

Intestinal barrier

Transepithelial resistance

F-actin cytoskeleton

\begin{abstract}
A B S T R A C T
Lactobacillus salivarius SMXD51 was previously isolated from the cecum of a Tunisian poultry and found to produce a bacteriocin-like substance highly active against the foodborne pathogen Campylobacter jejuni. The aim of this study was to examine some probiotic properties of the strain: acid and bile tolerance, capacity of adhesion, stimulation of immune defences (IL-6, IL-8, IL-10 and $\beta$-defensin 2 ), and modulation of the barrier integrity. The results showed that $L$. salivarius SMXD51 can tolerate gastrointestinal conditions (acid and bile), adhere to intestinal cells and stimulate the immune system. The bacterium strengthened the intestinal barrier functions through the increase of the transepithelial electrical resistance (TEER) and reinforcement of the F-actin cytoskeleton. One hour pretreatment with L. salivarius SMXD51 protected against Pseudomonas aeruginosa PAO1-induced decrease of TEER and damage of the F-actin cytoskeleton. Our results highlight that $L$. salivarius SMXD51 fulfils the principle requirements of an efficient probiotic and may be seen as a reliable candidate for further validation studies in chicken.
\end{abstract}

(C) 2012 Elsevier Ltd. All rights reserved.

\section{Introduction}

Antibiotics have been extensively used in animal feed to improve production in poultry and piglet industries [1]. However, the use of these substances as growth promoters can lead to the development of antibiotic resistances. Such resistances can occur not only in pathogenic bacteria $[2,3]$ which can be transferred from poultry products to human population [4], but also in commensal bacteria [5], constituting a reservoir of resistance genes for pathogenic bacteria [6]. Due to their potential to reduce enteric disease in poultry, probiotics are considered to be a good alternative to the use of antibiotics [7].

It is well-known that probiotics have a number of beneficial health effects in humans and animals. They play an important role in the protection of the host against harmful microorganisms and also strengthen the immune system [8]. Some probiotics have also been found to improve feed digestibility and reduce metabolic disorders [9]. They must be safe, acid and bile tolerant, able to

\footnotetext{
* Corresponding author. Tel.: +33232 2916 42; fax: +332 32291550 .

E-mail addresses: soumaya.messaoudi@oniris-nantes.fr (S. Messaoudi), amar.madi@univ-rouen.fr (A. Madi), herve.prevost@oniris-nantes.fr (H. Prévost), marc.feuilloley@univ-rouen.fr (M. Feuilloley), mohamed.manai@fst.rnu.tn (M. Manai), xavier.dousset@oniris-nantes.fr (X. Dousset), nathalie.connil@univrouen.fr (N. Connil).
}

adhere and colonize the intestinal tract [8]. Human enterocyte-like Caco- 2 cells have often been used for in vitro studies on the mechanisms of cellular adhesion of nonpathogenic Lactobacilli $[10,11]$. Some probiotic strains were shown to prevent attachment and invasion of various bacterial pathogens. Lactobacillus and Bifidobacterium were found to counteract Listeria infection of cultured epithelial cells through both secretion of antagonist molecules and modulation of the epithelial cell's immune response [12]. Compounds secreted by Lactobacillus were also shown to decrease in vivo the intestinal colonization by pathogenic strains of Escherichia coli [13]. Another and synergistic mechanism by which probiotics exert their beneficial effects is the enhancement of the intestinal barrier function. It has been found that treatment with probiotic bacteria may prevent or reverse increased permeability of the epithelium induced by pathogens [14]. These results were essentially obtained by measurement of the transepithelial electrical resistance (TEER) which appears as a reliable method to evaluate in vitro the epithelial permeability and compare the probiotic activity of bacterial species [15].

The genus Lactobacillus is commonly found in abundance in the upper gastrointestinal tract of humans and animals. Among this genus, within the recent years, Lactobacillus salivarius has gained attention as a promising probiotic species $[16,17]$ that influences cytokine profiles and modulates cellular responses to pathogenic challenge. In a recent study, we isolated $L$. salivarius SMXD51 from 
the cecum of a Tunisian poultry [18]. This strain was found to produce a bacteriocin-like substance active against Campylobacter jejuni, a bacterium known as a foodborn pathogen in humans and a common commensal of poultry [19]. The bacteriocin, salivaricin SMXD51 was purified and characterized [20]. In addition to Campylobacter, salivaricin SMXD51 showed inhibition against a number of foodborne pathogens, such as Listeria monocytogenes, Staphylococcus aureus and Salmonella. According to these results, L. salivarius SMXD51 may be a promising bioprotective strain for the control of pathogenic bacteria in meat products so in order to get more information about this interesting strain, we recently sequenced its genome [21].

In the present work, we aimed to investigate the in vitro probiotic potential of $L$. salivarius SMXD51 to evaluate if this strain could be considered as good alternative to antibiotics use in poultry production.

\section{Materials and methods}

\subsection{Bacterial strains}

L. salivarius SMXD51, isolated from the cecum of a Tunisian poultry [18] was cultivated at $37{ }^{\circ} \mathrm{C}$ in De Man-Rogosa-Sharpe (MRS) medium [22] for 18-24 h. Pseudomonas aeruginosa PAO1, a laboratory reference strain, was cultivated at $37^{\circ} \mathrm{C}$ in ordinary nutrient broth (Merck, France).

\subsection{Acid and bile tolerance}

Acid and bile tolerance were studied according to the protocol used by Anderson et al. (2010) [23]. Briefly, L. salivarius SMXD51 was grown overnight at $37{ }^{\circ} \mathrm{C}$ in MRS broth and suspended to an approximate cell concentration of $10^{8} \mathrm{CFU} / \mathrm{ml}$ in MRS broth adjusted to $\mathrm{pH} 3$ for $2 \mathrm{~h}$ and in $0.5 \% \mathrm{w} / \mathrm{v}$ bile (Sigma-Aldrich, France) for $4 \mathrm{~h}$. These conditions were chosen to represent the time it takes to pass through the gastrointestinal system and the $\mathrm{pH}$ value and bile concentration respectively found in the chicken stomach and intestine. Bacterial viability was assessed by enumeration on MRS agar plates.

\subsection{Cell line and culture}

The Caco-2/TC7 cells were used between passages 35 and 50 . Cells were routinely grown in Dulbecco's Modified Eagle's Medium (DMEM, Invitrogen, France) supplemented with $15 \%$ heatinactivated foetal calf serum, $2 \mathrm{mM}$ of L-glutamine, $100 \mathrm{U} / \mathrm{ml}$ each of penicillin and streptomycin and $1 \%$ non-essential amino acids. For experimental assays, the cells were seeded at a density of approximately $10^{5}$ cells $/ \mathrm{cm}^{2}$ in 24 -well tissue culture plates (for adhesion, cytotoxicity assay, cytokines and $\beta$-defensin 2 quantification) or on inserts ( $6.4 \mathrm{~mm}$ diameter, $3 \mu \mathrm{m}$ pore size, Falcon) which allow epithelial differentiation (for TEER assay and actin visualisation). The cells were cultured at $37{ }^{\circ} \mathrm{C}$ in $5 \% \mathrm{CO}_{2}-95 \%$ air atmosphere and the medium was regularly changed. Caco-2/TC7 grown in 24-well tissue culture plates were incubated to early confluence (undifferentiated state) whereas Caco-2/TC7 cells grown on inserts were used at 21 days post-confluence (fully differentiated state).

\subsection{Adhesion capacity}

L. salivarius SMXD51 was harvested by centrifugation, resuspended in cell culture medium without serum and antibiotics at a concentration of $10^{8} \mathrm{CFU} / \mathrm{ml}$, and then applied on confluent Caco2/TC7 monolayers. After $4 \mathrm{~h}$ of incubation at $37{ }^{\circ} \mathrm{C}, 5 \% \mathrm{CO}_{2}$, monolayers were washed with PBS to remove non adherent bacteria, and lysed by incubation for 15 min with $0.1 \%$ Triton X100. The lysates were then diluted and plated onto MRS agar to determine the number of adherent bacteria.

\subsection{Cytotoxicity assay}

After 24 h of incubation with L. salivarius SMXD51 $\left(10^{8} \mathrm{CFU} / \mathrm{ml}\right)$, the supernatants from Caco-2/TC7 monolayers grown on 24-well tissue culture plates were collected. The lactate dehydrogenase (LDH) present in the supernatants was measured using the Cytotox 96R enzymatic assay (Promega, France). LDH is a stable cytosolic enzyme of eukaryotic cells, indicator of necrotic cell death when released. Caco-2/TC7 cells exposed to Triton $\times 100(0.9 \%)$ were used as a control of total release ( $100 \% \mathrm{LDH}$ release) as recommended by the manufacturer's instructions. The background level (0\% LDH release) was determined with serum free culture medium. To complete the cytotoxicity assay, the integrity of Caco-2/TC7 monolayers was also estimated by observation with a photonic microscope $(\times 400)$.

\subsection{Quantification of $I L-6, I L-8, I L-10$ and $\beta$-defensin 2}

After 24 h of treatment with $10^{8} \mathrm{CFU} / \mathrm{ml}$ of $L$. salivarius SMXD51, the levels of cytokines (IL-6, IL-8 and IL-10) produced by Caco-2/ TC7 cells were measured in the culture supernatant using ELISA Quantikine kits (R\&D Systems, France). $\beta$-defensin 2 was quantified using the Defensin 2, beta (Human) - ELISA Kit (Phoenix, France).

\subsection{Transepithelial electrical resistance measurements}

The effect of $L$. salivarius SMXD51 on the transepithelial electrical resistance (TEER) of differentiated intestinal culture was studied during $24 \mathrm{~h}$, using the Millicell Electrical Resistance System (Millipore Corp, Bedford, MA). L. salivarius SMXD51 was incubated alone at $10^{8} \mathrm{CFU} / \mathrm{ml}$ on Caco-2/TC7 cell monolayers to determine the effect of this bacterium on the epithelial barrier integrity. The differentiated cells were also exposed to P. aeruginosa PAO1, a wellknown pathogen able to damage the barrier integrity, or preincubated with $L$. salivarius SMXD51 for $1 \mathrm{~h}$ before infection with the pathogen. For each conditions tested, TEER values were expressed as percentages of the initial level measured in the insert.

\subsection{Actin visualisation}

Fully differentiated Caco-2/TC7 monolayers were exposed either to L. salivarius SMXD51 or P. aeruginosa PAO1 for $24 \mathrm{~h}$ or preincubated for $1 \mathrm{~h}$ with $L$. salivarius SMXD51 before infection with the pathogen. At the end of the experiment, the cells were washed with phosphate-buffered saline (PBS), fixed for $10 \mathrm{~min}$ in $3.7 \%$ paraformaldehyde and permeabilized for $5 \mathrm{~min}$ with $0.1 \%$ Triton $\times 100$ at room temperature. The cells were then incubated with $1 \%$ bovine serum albumin in PBS for $10 \mathrm{~min}$ and the apical Factin cytoskeleton was stained by incubation with Alexa-488 phalloïdin (Invitrogen, France) for $45 \mathrm{~min}$ at room temperature (1U/insert). Following three washes in PBS, cell monolayers were excised from the filter supports, mounted on slides using Fluoromount Plus medium (Clinisciences, France) and examined using a confocal laser scanning microscope (Zeiss, LSM710).

\subsection{Statistical analysis}

Data are expressed as a mean \pm standard error (SE) calculated over three independent experiments performed in triplicate. 
Table 1

Evaluation of the probiotic properties of Lactobacillus salivarius SMXD51.

\begin{tabular}{|c|c|}
\hline Criteria tested & Results \\
\hline Resistance to acid & Yes. $99 \%$ survival after $2 \mathrm{~h}$ at $\mathrm{pH} 3$ \\
\hline Resistance to bile & Yes. $99 \%$ survival after $4 \mathrm{~h}$ at $0.5 \% \mathrm{w} / \mathrm{v}$ bile \\
\hline Adherence to intestinal cells & Yes. $10^{5} \mathrm{UFC} / \mathrm{ml}$ ( $1 \%$ of initial bacteria) \\
\hline Safety/cytotoxicity & $\begin{array}{l}\text { No cytotoxicity towards Caco- } 2 / \mathrm{TC} 7 \\
\text { (see Fig. 1A) } \\
\text { No visible damage on the monolayer } \\
\text { (see Fig. 1B) }\end{array}$ \\
\hline Modulation of immunity & $\begin{array}{l}\text { No-induction of IL- } 6 \text { (see Fig. } 2 \mathrm{~A} \text { ) } \\
\text { Induction of IL-8, } 1.8 \text {-fold increase (see Fig. 2B) } \\
\text { No-induction of IL-10 (see Fig. 2C) } \\
\text { Induction of } \beta \text {-defensin 2, 2.6-fold } \\
\text { increase (see Fig. 2D) }\end{array}$ \\
\hline Barrier integrity & $\begin{array}{l}\text { Enhancement in TEER, } 1.2 \text { fold increase } \\
\text { (see Fig. 3) } \\
\text { Protection of F-actin (see Fig. 4) }\end{array}$ \\
\hline $\begin{array}{l}\text { Antimicrobial activity against } \\
\text { pathogenic bacteria }\end{array}$ & $\begin{array}{l}\text { Yes, previous study (Messaoudi } \\
\text { et al., 2012) [16] }\end{array}$ \\
\hline
\end{tabular}

Analysis of statistical significance was performed by ANOVA with Student's $t$-test.

\section{Results and discussion}

L. salivarius SMXD51 was evaluated in regard of the typical probiotic properties proposed by Gupta and Garg (2009) [24] and Neville and O'Toole (2010) [17]. Results are summarized in Table 1.

\subsection{Acid and bile tolerance}

Resistance to acid and bile is generally considered an essential assessment criterion for probiotic evaluation since the strains have to survive the conditions in the stomach and the small intestine [17]. Thus, the survival of $L$. salivarius SMXD51 was tested for $2 \mathrm{~h}$ at $\mathrm{pH} 3$ and $4 \mathrm{~h}$ in $0.5 \% \mathrm{w} / \mathrm{v}$ bile. The results show that this strain was able to tolerate acidic conditions and the presence of $0.5 \% \mathrm{w} / \mathrm{v}$ bile without any significant loss of viability (99\% survival). In these physiological conditions, the behaviour of $L$. salivarius SMXD51 was similar to the results previously obtained by Kirtzalidou et al. [25] for $L$. salivarius C3 isolated from the infant gut microbiota, and by Yun et al. (2009) [26] for L. salivarius LB64 from pig feces.

Sequencing of $L$. salivarius SMXD51 by Kergourlay et al. (2012)[21] revealed that several genes known to be important for acid tolerance and bile salt resistance were found in the genome of the bacteria, among them an ornithine decarboxylation-antiporter system and a bile salt hydrolase family protein choloylglycine hydrolase. The presence of these genes may partially explain the ability of L. salivarius SMXD51 to resist to the gastrointestinal conditions tested.

\subsection{Adhesion capacity}

Adherence to intestinal epithelial cells is another reliable criterion for the selection of probiotic. In vitro test results using Caco-2 cell for the estimation of adhesion capacity to intestinal epithelium cells have been reported to have a good correlation to in vivo results [27] and this characteristic is often strain-specific. Adhesion capacity of $L$. salivarius SMXD51 $\left(10^{8} \mathrm{CFU} / \mathrm{ml}\right)$ was examined by incubating the bacteria with confluent Caco-2/TC7 monolayers for $4 \mathrm{~h}$. At the end of incubation period, non adherent bacteria were removed by rinsing and the number of adherent germs was determined by plating. In these conditions $10^{5} \mathrm{CFU} / \mathrm{ml}$ adherent L. salivarius SMXD51, corresponding to $1 \%$ of the initial population, were recovered in the Caco-2/TC7 monolayers lysates. This strain demonstrates a capacity of adhesion at least identical or higher than L. salivarius C3 previously tested by Kirtzalidou et al. (2011) [25]. We found that $L$. salivarius SMXD51 have high hydrophobic affinity towards $n$-hexadecane (data not shown). This characteristic may promote hydrophobic interactions which are generally considered to play an important role in the adherence of microorganisms to eukaryotic cells [28]. Moreover, analysis of the sequence of L. salivarius SMXD51 by Kergourlay et al.(2012) [21] showed recently the presence of two genes encoding cell wall-anchored adhesin that may be involved in adherence to eukaryotic cells, a fibronectin binding protein (FbpA) and a potential mucus adhesion-promoting protein (MapA). The lspA gene from $L$. salivarius UCC118 reported to mediate adhesion was also found with $92.6 \%$ identity.

\subsection{Cytotoxicity assay}

The safety of lactobacilli and bifidobacteria is well documented. In general, the pathogenic potential of these normal colonizers of the human body is considered quite low [29]. Only very rare cases of human infection (commonly endocarditis) have been reported $[30,31]$. However, further investigation is warranted for probiotic use in at-risk human populations such as severely immunocompromised subjects, neonates or hospitalized patients. For such sensitive populations, the use of appropriate in vitro assays to assess the safety of probiotics should not be precluded. L. salivarius
A

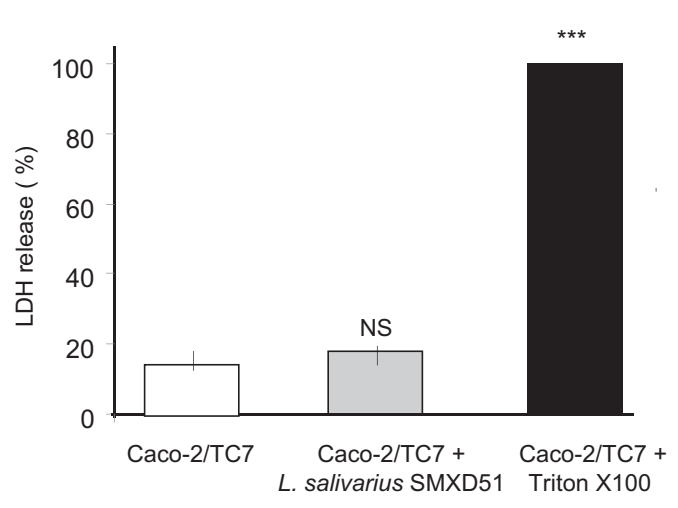

B

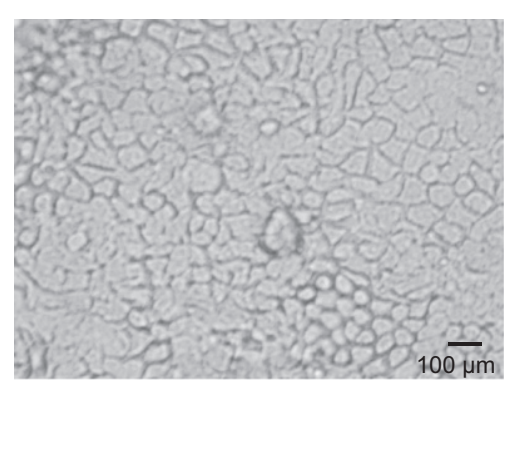

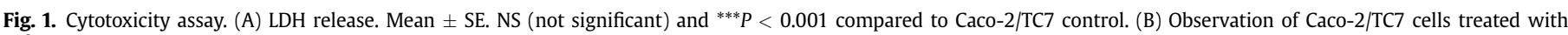
$10^{8} \mathrm{CFU} / \mathrm{ml}$ of $L$. salivarius SMXD51 with a photonic microscope. 
SMXD51 $\left(10^{8} \mathrm{CFU} / \mathrm{ml}\right)$ were applied on Caco-2/TC7 monolayers for $24 \mathrm{~h}$ and the cytotoxicity was evaluated by measurement of LDH release and microscopic observation. The results show that the amount of LDH release in the supernatant of Caco-2/TC7 cultured in the absence or presence of the bacteria was unchanged, indicating that $L$. salivarius SMXD51 didn't cause cell lysis (Fig. 1A). The absence of cytotoxicity of $L$. salivarius SMXD51 against Caco-2/TC7 cells was confirmed by microscopic studies. Even after $24 \mathrm{~h}$ of incubation with the bacteria, the integrity of the monolayer was fully preserved (Fig. 1B).

\subsection{Quantification of IL-6, IL-8, IL-10 and $\beta$-defensin 2}

Another criterion often screened for the selection of probiotics is their capacity to modulate the immune system [32,33]. The quantification of IL-6, IL-8, IL-10 and $\beta$-defensin 2 using ELISA assays showed that $L$. salivarius SMXD51 induces 1.8 -fold increase in IL-8 secretion (Fig. 2B) and 2.6-fold increase in $\beta$-defensin 2 secretion (Fig. 2D) compared to untreated Caco-2/TC7 cells. On the contrary, for IL-6 (Fig. 2A) and IL-10 (Fig. 2C), no variation of the basal secretion of Caco-2/TC7 cells was observed after exposure to the bacteria. These results are consistent with those of Perez-Cano et al. [34] who showed that Lactobacillus fermentum CECT5716 and L. salivarius CECT5713 display in vitro immunomodulatory activity by induction of IL-8. However, in contrast with our results, L. fermentum CECT5716 and $L$. salivarius CECT5713 also promoted the production of the proinflammatory IL-6 and anti-inflammatory IL-10. These differences are not surprising since the immunomodulatory effects are often strain-specific $[35,36]$. We also observed that $L$. salivarius SMXD51 induced the secretion of $\beta$-defensin 2 . It is known that inducible $\beta$ defensins play an important role in the intestinal barrier function and in vitro studies have shown that clinically effective probiotics induce the production of antimicrobial $\beta$-defensin 2 [37-39]. Induction of $\beta$-defensin 2 by probiotics, including $L$. salivarius SMXD51, might be an alternative and a complementary new strategy to strengthen innate defence mechanisms.

\subsection{Effect of L. salivarius SMXD51 on TEER and the F-actin cytoskeleton}

Modulation of the barrier integrity was studied to provide further support for the probiotic properties of $L$. salivarius SMXD51.

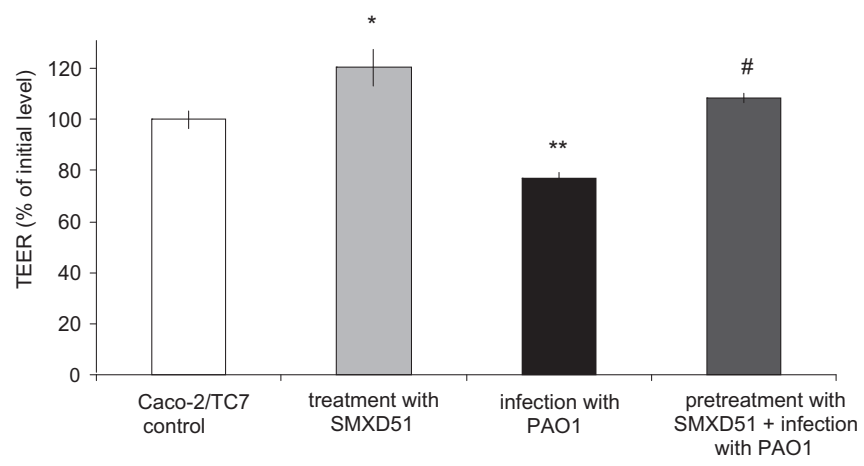

Fig. 3. TEER of Caco-2/TC7 cells exposed to L. salivarius SMXD51, P. aeruginosa PAO1 or a combination of the two strains. Data are expressed as percentages of the initial level measured in the insert and as a mean $\pm \mathrm{SE}$. ${ }^{*} \mathrm{P}<0.05$ and ${ }^{* *} \mathrm{P}<0.01$ compared to Caco$2 /$ TC7 control. $\# P<0.01$ compared to infection with PAO1.

Caco-2/TC7 cells were treated with $L$. salivarius SMXD51 during $24 \mathrm{~h}$. The results showed that the bacteria induce a $20 \pm 7 \%$ increase of the TEER of the monolayer (Table 1, and Fig. 3). Confocal microscopy observations confirmed that the network of the F-actin cytoskeleton was more dense after $24 \mathrm{~h}$ incubation with $L$. salivarius SMXD51 (Fig. 4B) compared to an untreated control (Fig. 4A). The use of transepithelial electrical resistance of intestinal epithelial cell monolayers as a mean to evaluate probiotic activity was first proposed by Klingberg et al. [15]. They investigated the probiotic potential of five lactobacilli strains and found that Lactobacillus plantarum MF1298 and L. salivarius DC5 showed the highest increase in TEER in a dose dependent manner. The maximal increase of TEER obtained was about $40 \%$ after $24 \mathrm{~h}$ of incubation with the probiotics.

\subsection{Protection of the barrier integrity by L. salivarius SMXD51}

We evaluated if $L$. salivarius SMXD51 can prevent the loss of barrier integrity provoked by a pathogen, i.e. P. aeruginosa PAO1. This strain was chosen as model for alteration of the intestinal epithelium because it has been previously shown to have a strong cytotoxic activity towards Caco-2/TC7 cells and be able to disrupt the F-actin cytoskeleton [40]. Our results revealed that when Caco-2/TC7 cells were infected with $P$. aeruginosa PAO1 $\left(10^{6} \mathrm{CFU} / \mathrm{ml}\right)$, the TEER was decreased by a mean of $25 \pm 3 \%$ (Fig. 3) and the F-actin cytoskeleton
A

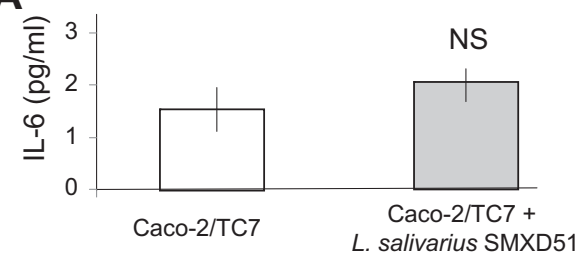

C

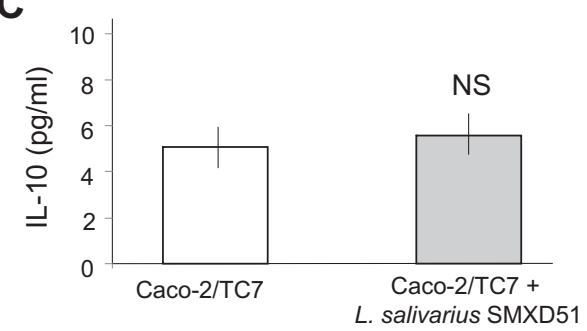

B

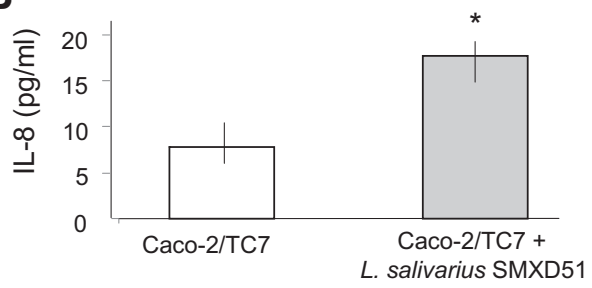

D

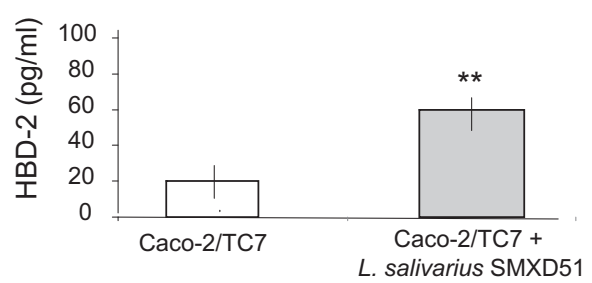

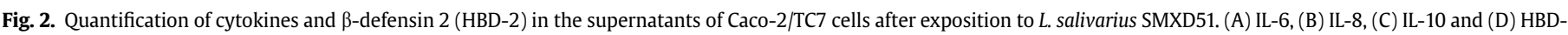
2. Mean \pm SE. NS (not significant), ${ }^{*} P<0.05$ and ${ }^{* *} P<0.01$ compared to Caco- $2 /$ TC7 control. 

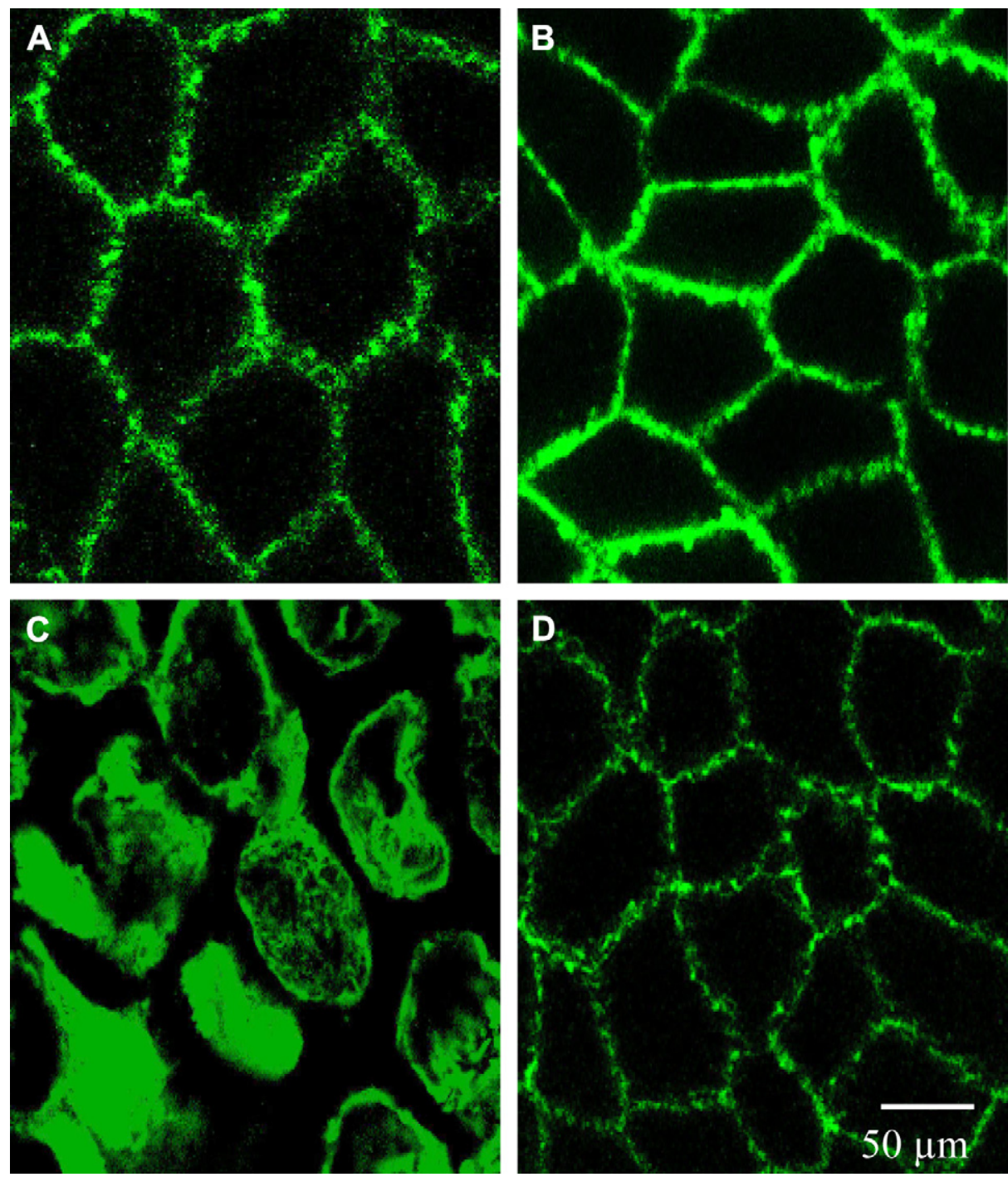

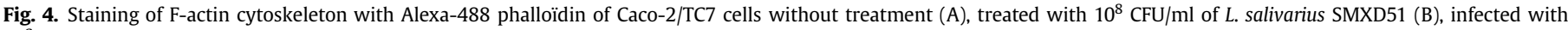
$10^{6} \mathrm{CFU} / \mathrm{ml}$ of $P$. aeruginosa PAO1 (C), or pretreated with SMXD51 and then infected with PAO1 (D).

was seriously damaged (Fig. 4C). Preincubation of Caco-2/TC7 cells with $L$. salivarius SMXD51 $\left(10^{8} \mathrm{CFU} / \mathrm{ml}\right)$ prevented the deleterious $P$. aeruginosa PAO1-induced TEER changes (Fig. 3 ) and the cytoskeleton disruption (Fig. 4D). However, this effect was only observed when L. salivarius SMXD51 is added $1 \mathrm{~h}$ before the infection with the pathogen. When the two bacteria were added simultaneously, L. salivarius SMXD51 failed to prevent the loss of barrier integrity (data not shown). It could be suggested that when $L$. salivarius SMXD51 is used in prevention to the infection, the bacteria may form a physical protection barrier on the monolayer that refrains the access of the pathogen to the eukaryotic receptor by occupying the target sites. Moreover, during the pretreatment, L. salivarius SMXD51 may have time to secrete some molecules that will have antagonistic activities against $P$. aeruginosa PAO1. Similar mechanisms for other probiotics have been described previously. Liu et al. [41] found that L. plantarum prevented the decrease in the expression of tight junction proteins and F-actin in NCM460 cells infected with enteroinvasive E. coli (EIEC) or enteropathogenic E. coli (EPEC). Another study found that Lactobacillus rhamnosus GG protected epithelial monolayers against enterohaemorrhagic E. coli (EHEC)-induced redistribution of the claudin-1 and ZO-1 tight junction proteins. Lactobacillus acidophilus protected against F-actin rearrangement induced in an epithelial cell line upon exposure to a pathogenic E. coli [42]. Streptococcus thermophilus and L. acidophilus maintained (actin, ZO-1) or enhanced (actinin, occludin) cytoskeletal and tight junctional protein structures in epithelial cell lines [14]. Similarly, E. coli Nissle 1917 can counteract the disruptive effects of EPEC on T84 epithelial cells tight junctions [43].

\section{Conclusion}

This study shows that $L$. salivarius SMXD51 fulfils to all the principle requirements and properties of an efficient probiotic (tolerance to gastrointestinal conditions, adhesion to intestinal cells, stimulation of immunity, and reinforcement of epithelial barrier). These findings demonstrated that $L$. salivarius SMXD51 could be a reliable candidate for future use as probiotic in chicken feed supplement. Further investigations will be conducted in animal experiments to assess the in vivo efficacy of the strain.

\section{Acknowledgements}

This study was supported by Région Pays de la Loire. SM was a recipient of a PhD scholar fellowship awarded by French Ministry 
of foreign affairs through CMCU program (Joint French - Tunisian program) and ONIRIS.

\section{References}

[1] Guerra NP, Bernárdez PF, Méndez J, Cachaldora P, Pastrana Castro L. Production of four potentially probiotic lactic acid bacteria and their evaluation as feed additives for weaned piglets. Anim Feed Sci Technol 2007;134:89-107.

[2] Aarestrup FM, Bager F, Andersen SJ. Association between the use of avilamycin for growth promotion and the occurrence of resistance among Enterococcus faecium from broilers: epidemiological study and changes over time. Microb Drug Resist 2000;6:71-5.

[3] Randall LP, Ridley AM, Cooles SW, Sharma M, Sayers AR, Pumbwe L, et al. Prevalence of multiple antibiotic resistance in 443 Campylobacter spp. isolated from humans and animals. J Antimicrob Chemother 2003;52:507-10.

[4] van den Bogaard AE, Stobberingh EE. Epidemiology of resistance to antibiotics: links between animals and humans. Int J Antimicrob Agents 2000;14: $327-35$.

[5] Lukášová J, Šustáčková A. Enterococci and antibiotic resistance. Acta Veterinaria Brno 2003;72:315-23.

[6] Apata DF. Antibiotic resistance in poultry. Int J Poult Sci 2009;8:404-8.

[7] Patterson JA, Burkholder KM. Application of prebiotics and probiotics in poultry production. Poult Sci 2003;82:627-31.

[8] Soccol CR, de Souza Vandenberghe LP, Spier MR, Medeiros ABP, Yamaguishi CT, Lindner JDD, et al. The potential of probiotics: a review. Food Technol Biotechnol 2010;48:413-34.

[9] Kumar M, Nagpal R, Kumar R, Hemalatha R, Verma V, Kumar A, et al. Cholesterol-lowering probiotics as potential biotherapeutics for metabolic diseases. Exp Diabetes Res 2012;2012:902917.

[10] Chauvière G, Coconnier MH, Kernéis S, Fourniat J, Servin AL. Adhesion of human Lactobacillus acidophilus strain LB to human enterocyte-like Caco-2 cells. J Gen Microbiol 1992;138:1689-96.

[11] Ferreira CL, Grześkowiak L, Collado MC, Salminen S. In vitro evaluation of Lactobacillus gasseri strains of infant origin on adhesion and aggregation of specific pathogens. J Food Prot 2011;74:1482-7.

[12] Corr SC, Gahan CG, Hill C. Impact of selected Lactobacillus and Bifidobacterium species on Listeria monocytogenes infection and the mucosal immune response. FEMS Immunol Med Microbiol 2007;50:380-8.

[13] Medellin-Peña MJ, Griffiths M. Effect of molecules secreted by Lactobacillus acidophilus strain La-5 on Escherichia coli 0157:H7 colonization. Appl Environ Microbiol 2009;75:1165-72.

[14] Resta-Lenert S, Barrett KE. Live probiotics protect intestinal epithelial cells from the effects of infection with enteroinvasive Escherichia coli (EIEC). Gut 2003;52:988-97.

[15] Klingberg TD, Pedersen MH, Cencic A, Budde BB. Application of measurements of transepithelial electrical resistance of intestinal epithelial cell monolayers to evaluate probiotic activity. Appl Environ Microbiol 2005;71:7528-30.

[16] Dunne C, O’Mahony L, Murphy L, Thornton G, Morrissey D, O'Halloran S, et al. In vitro selection criteria for probiotic bacteria of human origin: correlation with in vivo findings. Am J Clin Nutr 2001;73:386S-92S.

[17] Neville BA, O'Toole PW. Probiotic properties of Lactobacillus salivarius and closely related Lactobacillus species. Future Microbiol 2010;5:759-74.

[18] Messaoudi S, Kergourlay G, Rossero A, Ferchichi M, Prévost H, Drider D, et al. Identification of lactobacilli residing in chicken ceca with antagonism against Campylobacter. Int Microbiol 2011;14:103-10.

[19] Silva J, Leite D, Fernandes M, Mena C, Gibbs PA, Teixeira P. Campylobacter spp. as a foodborne pathogen: a review. Front Microbiol 2011;2:200.

[20] Messaoudi S, Kergourlay G, Dalgalarrondo M, Choiset Y, Ferchichi M, Prévost $\mathrm{H}$, et al. Purification and characterization of a new bacteriocin active against Campylobacter produced by Lactobacillus salivarius SMXD51. Food Microbiol 2012;32:129-34.

[21] Kergourlay G, Messaoudi S, Dousset X, Prévost H. Genome sequence of Lactobacillus salivarius SMXD51, a potential probiotic strain isolated from chicken cecum, showing anti-campylobacter activity. J Bacteriol 2012;194: 3008-9.
[22] De Man JCA, Rogosa M, Sharpe ME. A medium for the cultivation of lactobacilli. J Appl Bacteriol 1964;23:130-6.

[23] Anderson RC, Cookson AL, McNabb WC, Kelly WJ, Roy NC. Lactobacillus plantarum DSM 2648 is a potential probiotic that enhances intestinal barrier function. FEMS Microbiol Lett 2010;309:184-92.

[24] Gupta V, Garg R. Probiotics. Indian J Med Microbiol 2009;27:202-9.

[25] Kirtzalidou E, Pramateftaki P, Kotsou M, Kyriacou A. Screening for lactobacilli with probiotic properties in the infant gut microbiota. Anaerobe 2011;17: 440-3.

[26] Yun JH, Lee KB, Sung YK, Kim EB, Lee HG, Choi YJ. Isolation and characterization of potential probiotic lactobacilli from pig feces. J Basic Microbiol 2009;49:220-6.

[27] Crociani J, Grill JP, Huppert M, Ballongue J. Adhesion of different bifidobacteria strains to human enterocyte-like Caco-2 cells and comparison with in vivo study. Lett Appl Microbiol 1995;21:146-8.

[28] Oliveira R, Azeredo J, Teixeira P, Fonseca AP. The role of hydrophobicity in bacterial adhesion. In: Gilbert P, Allison D, Brading M, Verran J, Walker J, editors. Biofilm community interactions: chance or necessity? Wales, UK: Bioline, Cardiff University; 2001. p. 11-22.

[29] Borriello SP, Hammes WP, Holzapfel W, Marteau P, Schrezenmeir J, Vaara M, et al. Safety of probiotics that contain lactobacilli or bifidobacteria. Clin Infect Dis 2003;36:775-80.

[30] Tommasi C, Equitani F, Masala M, Ballardini M, Favaro M, Meledandri M, et al. Diagnostic difficulties of Lactobacillus casei bacteraemia in immunocompetent patients: a case report. J Med Case Rep 2008;2:315.

[31] Fradiani PA, Petrucca A, Ascenzioni F, Di Nucci G, Teggi A, Bilancini S, et al. Endocarditis caused by Lactobacillus jensenii in an immunocompetent patient. J Med Microbiol 2010;59:607-9.

[32] Amit-Romach E, Uni Z, Reifen R. Multistep mechanism of probiotic bacterium, the effect on innate immune system. Mol Nutr Food Res 2010:54·277-84.

[33] Wells JM. Immunomodulatory mechanisms of lactobacilli. Microb Cell Fact 2011;10(Suppl. 1):S17.

[34] Pérez-Cano FJ, Dong H, Yaqoob P. In vitro immunomodulatory activity of Lactobacillus fermentum CECT5716 and Lactobacillus salivarius CECT5713: two probiotic strains isolated from human breast milk. Immunobiology 2010;215: 996-1004.

[35] Lammers KM, Helwig U, Swennen E, Rizzello F, Venturi A, Caramelli E, et al. Effect of probiotic strains on interleukin 8 production by HT29/19A cells. Am J Gastroenterol 2002;97:1182-6.

[36] Helwig U, Lammers KM, Rizzello F, Brigidi P, Rohleder V, Caramelli E, et al. Lactobacilli, bifidobacteria and $E$. coli nissle induce pro- and anti-inflammatory cytokines in peripheral blood mononuclear cells. World J Gastroenterol 2006; 12:5978-86.

[37] Wehkamp J, Harder J, Wehkamp K, Wehkamp-von Meissner B, Schlee M, Enders C, et al. NF-kappaB- and AP-1-mediated induction of human beta defensin-2 in intestinal epithelial cells by Escherichia coli Nissle 1917: a novel effect of a probiotic bacterium. Infect Immun 2004;72:5750-8.

[38] Schlee M, Harder J, Köten B, Stange EF, Wehkamp J, Fellermann K. Probiotic lactobacilli and VSL\#3 induce enterocyte beta-defensin 2. Clin Exp Immunol 2008;151:528-35.

[39] Möndel M, Schroeder BO, Zimmermann K, Huber H, Nuding S, Beisner J, et al. Probiotic E. coli treatment mediates antimicrobial human beta-defensin synthesis and fecal excretion in humans. Mucosal Immunol 2009;2:166-72.

[40] Madi A, Svinareff P, Orange N, Feuilloley MG, Connil N. Pseudomonas fluorescens alters epithelial permeability and translocates across Caco-2/TC7 intestinal cells. Gut Pathog 2010;2:16.

[41] Liu ZH, Shen TY, Zhang P, Ma YL, Moyer MP, Qin HL. Protective effects of Lactobacillus plantarum against epithelial barrier dysfunction of human colon cell line NCM460. World J Gastroenterol 2010;16:5759-65.

[42] Liévin-Le Moal V, Amsellem R, Servin AL, Coconnier MH. Lactobacillus acidophilus (strain LB) from the resident adult human gastrointestinal microflora exerts activity against brush border damage promoted by a diarrhoeagenic Escherichia coli in human enterocyte-like cells. Gut 2002;50:803-11.

[43] Zyrek AA, Cichon C, Helms S, Enders C, Sonnenborn U, Schmidt MA. Molecular mechanisms underlying the probiotic effects of Escherichia coli Nissle 1917 involve ZO-2 and PKCzeta redistribution resulting in tight junction and epithelial barrier repair. Cell Microbiol 2007;9:804-16. 